DOI https://doi.org/10.30525/978-9934-26-117-6-38

\title{
ШРИФТОВА КОМПОЗИЦІЯ РУКОТВОРНОГО ГРАФІЧНОГО НАПИСУ У ВІЗУАЛЬНОМУ СЕРЕДОВИЩІ МІСТА
}

\author{
Пандирсва С. A. \\ аспірант кафедри теорії та історії мистеитьв \\ Павлова Т. В. \\ професор, доктор мистецтвознавства, \\ завідувач кафедри візуальних практик \\ Харківська державна академія дизайну і мистецтв \\ м. Харків, Україна
}

Будь-яка шрифтова композиція, якою б вона не була, несе в собі певне значення, навіть якщо не передає ніякої інформації. Будучи виконана автором, вона все одно через свою форму відображає певні якості - віртуозність, довершеність володіння інструментом, культуру виконавця тощо. Композиція шрифтової графіки може будуватися на основі використання одного або декількох шрифтових елементів, або літер всього алфавіту [2, с. 110].

Шрифтова композиція рукотворного графічного напису у візуальному середовищі міста може розглядатися з двох позицій:

- По-перше - як певна система організації графічних елементів рукотворного графічного шрифту з метою повідомлення інформації;

- По-друге - як твір графічного мистецтва, що виконаний за допомогою елементів алфавіту.

У першому випадку можна дати якісну оцінку композиції за допомогою визначень: чітка, стримана, легко читається тощо. Ці поняття свідчать про якості шрифтової композиції рукотворного графічного напису. Якісний рівень шрифтової композиції інформаційного характеру, може бути різний і залежить від цілей, які ставить перед собою автор:

1. Функиіональні - основна увага приділяється забезпеченню однозначності і максимальній доступності інформації, що передається (рис. 1); 


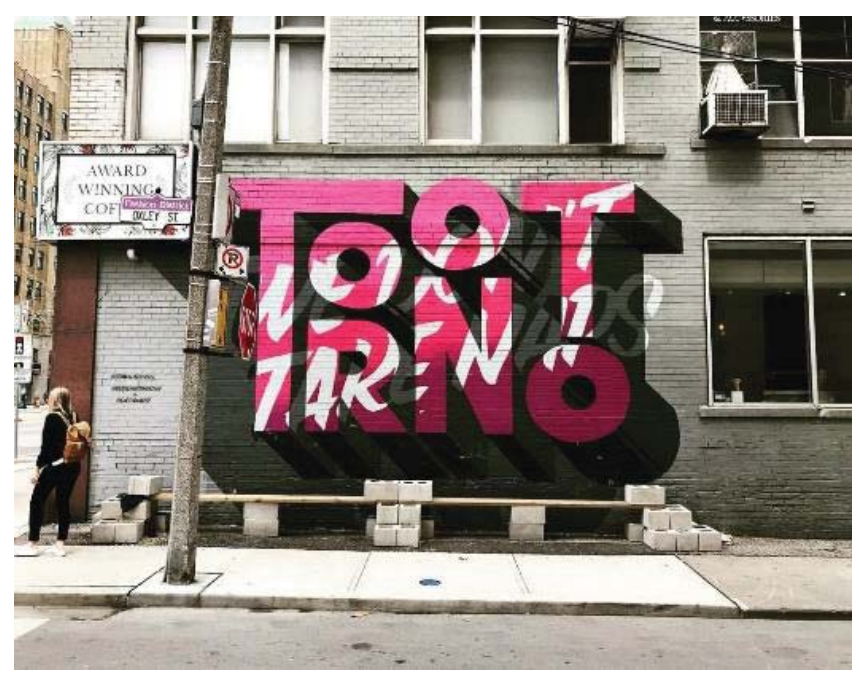

Рис. 1 Бен Джонсон. «Toronto». 101 Spadina Avenue.

Онтаріо, Канада. 2018.

2. Змістовні - створюються за допомогою введенню графічних елементів, що створюють певну ступінь образності графіки шрифту (рис. 2);

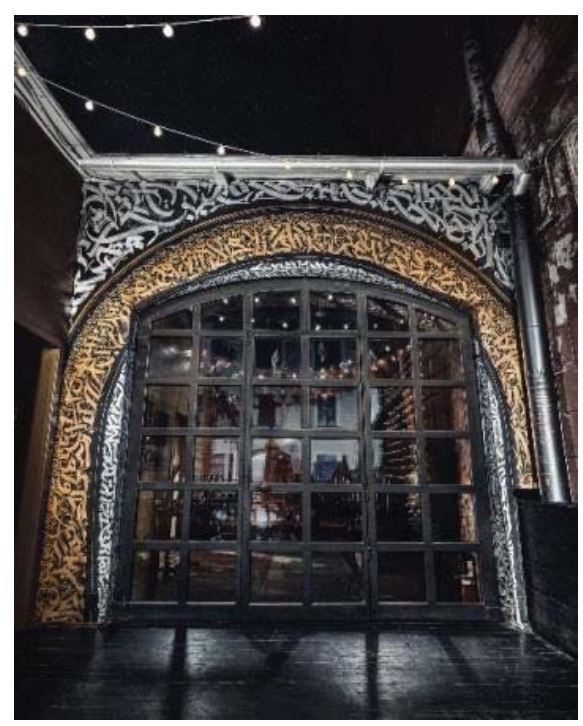

Рис. 2 Лампас Покрас. Розпис арки в «Скотном дворе». СанктПетербург, Росія. 2020

3. Формальні - властиві шрифтовим композиціям, в яких природно і логічно обумовлені зв'язки елементів і частин літер або наявна більш складна шрифтова графіка (рис. 3). 


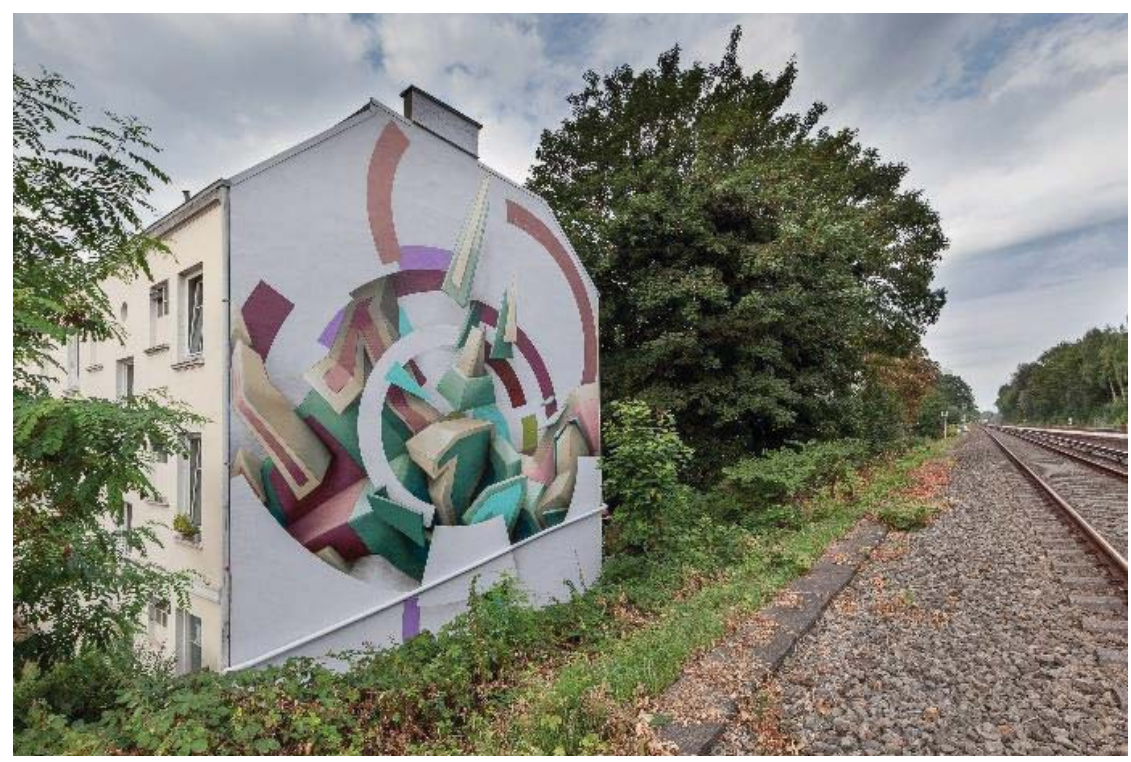

\section{Рис. 3 DAIM. «diagramm Test 01». Гамбург, Німеччина. 2018}

Основа шрифтової композиції рукотворного графічного напису будується на відносинах змісту і форми. Залежно від того, що панує в композиції, вона може бути:

- формально-змістовна - форма переважає над змістом (зазвичай, фахівці, що працюють в стилі графіті обирають такий тип композиції);

- змістовно-формальна - зміст переважає над формою (цьому типу віддають перевагу фахівці, що працюють 3 рисованим шрифтом та в художній формі каліграфіті).

Оптичні ілюзї в шрифті. При написанні чи малюванні шрифту автор повинен знати і враховувати, що в певних умовах різні елементи можуть виглядати однаковими, i навпаки. Причина такого явища закладена в оптичних особливостях очей людини і їі психіки. Видима якість оригіналу, що не відповідає дійсності, називають оптичною ілюзією. При роботі над малюнком літер шрифту слід пам'ятати, що через оптичні ілюзії, правильно побудоване зображення може здаватися неправильним. У деяких випадках художник повинен навмисно спотворювати зображення літери, щоб домогтися оптично рівної висоти всіх літер.

3 оптичними ілюзіями пов'язаний також вплив іррадіаціï - позірна зміна площі кольорової плями, оточеного фоном, який вирізняється від нього по світлості. Наприклад, чорне коло на білому тлі здається менше, ніж білий круг такого ж діаметру на чорному. Це явище добре спостерігається в шрифтах на виворіт. Необхідно враховувати явище іррадіації при виконанні шрифтових написів, коли одна їх частина зроблена чорним по білому, а інша - білим по чорному (принцип 
іррадіації дуже часто полюбляють використовувати фахівці, що працюють в художній формі каліграфіті).

Оптичні ілюзії проявляються не тільки в розмірних вимірах (ширше, вужче, вище, нижче), але і в об'ємних. Залежно від силуету малюнка літери, насиченості штрихів, фону, на якому вона написана, можна зобразити її об'ємно або плоско на площині у середовищі міста [2, с. 80]. Працюючи над шрифтовою композицією, бажано враховувати обраний вид малювання чи письма рукотворного графічного напису. Наприклад, в рисованому шрифті чи каліграфіті рядки однієї композиції повинні знаходитися в однакових оптичних площинах, а більшість стилів графіті навпаки базуються на ігноруванні оптичних площин та суцільній деформації конструкції літер.

Ритм в шрифті проявляється в побудові окремих літер, слів, рядків і навіть певних архітектурних елементів у візуальному середовищі міста, що також можуть задавати ритм створюваного напису. Рівномірне чергування, повторення однакових елементів утворюють певний ритм. Геометрична і оптична пропорційність літер і окремих елементів сприяє ритмічній побудові шрифту [2, с. 77]. На макрорівні ритм в шрифті повинен підпорядковуватися загальному авторському рішенню. На мікрорівні може проявляти себе в конструкції окремого знаку. Головна функція графічного риму в шрифті - посилення видимого зв’язку знаків між собою, додавання ритму [1, с. 41].

Змінюючи пропорції літер, автор може надавати шрифту різноманітну ритмічну спрямованість - відчуття умовного руху, внутрішньої динаміки, яке викликане чергуванням повторюваних елементів літер. Оволодіння ритмом дозволяє впливати на процес читання. Особливість ритмічної побудови полягає і в тому, що ритм не тільки допомагає читати, а й створює певний зоровий образ слова, що зберігається в нашій пам'яті [2, с. 78].

Висновки. Визначено, що шрифтова композиція рукотворного графічного напису у візуальному середовищі міста має свої особливості. Вона залежить від того, що переважає в композиції - форма над змістом чи навпаки, а також залежить від цілей, які ставить перед собою автор: функціональні, змістовні, формальні. 3'ясовано, чому при малюванні чи написанні напису автор повинен враховувати оптичні ілюзії, явище іррадіації та як проявляється ритм у шрифті.

\section{Література:}

1. Гордон Ю. Вся книга про буквы от Аа до Яя. Москва: Изд-во Студии Артемия Лебедева. 2006. 384 с. 
2. Таранов Н. Н. Художественно-образная выразительность шрифтов: монография. Волгоград: Перемена. 2000. 168 с.

DOI https://doi.org/10.30525/978-9934-26-117-6-39

\title{
АНІМАЛІСТИЧНІ ОБРАЗИ В ТВОРЧОСТІ ВІРИ БАРИНОВОЇ-КУЛЕБИ
}

\author{
Петрук P. I. \\ заслужений діяч мистеитв України, \\ дочент кафедри монументально-декоративного \\ і сакрального мистеитвва
}

Київська державна академія декоративно-прикладного мистецтва і дизайну імені Михайла Бойчука м. Київ, Україна

Творчий доробок відомої української художниці Віри Іванівни Баринової-Кулеби (нар. 1938) налічує сотні живописних творів, різних за тематикою й манерою візуалізації та стилізації образів, серед яких, окрім портретів й натюрмортів, домінують українські фольклорні зображення, пасторальні сцени. Зауважимо, що мисткиня нерідко звертається до анімалістичного жанру, змальовуючи на своїх полотнах побут українського села, з його звичаями та традиціями, зображуючи поряд 3 людьми тварин. Саме тому анімалістичні образи у творчості В. Баринової-Кулеби потребують окремого наукового зосередження.

Анімалістичний - один із найдавніших жанрів образотворчого мистецтва України і світу. Перші зображення тварин, що збереглись дотепер, відомі нам ще $з$ періоду пізнього палеоліту. В усі часи люди малювали тварин та птахів, надаючи своїм зображенням певних символічних значень, які можливо зрозуміти, лише дослідивши контекст.

Творчий шлях української художниці й педагога Віри БариновоїКулеби розпочався на хуторі Мельникове-Кулебине на Полтавщині. Про це мисткиня написала триптих «Ото ж було...» (2017; іл. 1), на центральній частині якого окремим текстуальним фрагментом виділено: «Ото ж було... 1940 р. Хутір Мельнико-Кулебино переселяли у село Римарівку, Гадяцького р-н, Полтавської обл. ближче до колгоспу. <...> Зруйнували церкву на іконах обдирали позолоту. <..> Моя баба спасла одну ікону, замотавши у мішок. Батько тяг із усім збіжжям гарбу. Мама несла Петруся і трьох курей. Я переляканого 